\title{
White-Collar Crime Triangle: Finance, Organization and Behavior
}

\author{
Petter Gottschalk* \\ BI Norwegian Business School, Europe
}

Submission: July 24, 2017; Published: August 04, 2017

*Corresponding author: Petter Gottschalk, BI Norwegian Business School, Nydalsveien 37, 0484 Oslo, Norway, Europe, Tel: 4792011837;

Email: petter.gottschalk@kruttforlag.no

\begin{abstract}
White-collar crime is committed by members of the elite in society in their privileged roles in professional settings. White-collar crime can be explained by convenience theory, which suggests that crime occurs when there is a strong financial desire, convenient organizational opportunity, and willingness to adopt deviant behavior. In this article, the triangle of financial motive, organizational opportunity and deviant behavior is introduced as predictor of the tendency to commit white-collar crime. Multiple item scales are presented for each concept, which were applied in a questionnaire. Research results provide support for the triangle as a significant and strong predictor of criminogenity, where personal willingness to commit crime stands out as the main explanatory factor.
\end{abstract}

Keywords: Fraud triangle; White-collar crime; Regression analysis; Deviant behavior

\section{Introduction}

Cressey's [1] fraud triangle examined the motivation for crime. McMahon et al. [2] suggest there is a need to move beyond the traditional fraud triangle to fight white-collar crime. In this article, we suggest a white-crime triangle which includes financial motive, organizational opportunity and deviant behavior. The suggested white-collar crime triangle is based on convenience theory [3], where white-collar crime can be explained by financial desires, organizational concealment and rationalization of criminal behavior. Convenience is a relative concept, where an illegal path may be more convenient than a legal path when considering potential benefits and costs. Potential benefits may be avoidance of pain and suffering, while potential costs may be detection and conviction. In this article, we suggest a research model to predict the extent of financial crime based on the white-collar crime triangle. We ask the following research question: What determines the tendency towards white-collar crime depending on financial motive, organizational opportunity and acceptable behavior?

\section{Convenience Theory}

As suggested by, white-collar crime can be a convenient option to avoid threats and exploit possibilities [4]. Convenience orientation is conceptualized as the value that individuals and organizations place on actions with inherent characteristics of saving time and effort. Convenience orientation can be considered a value-like construct that influences behavior and decision-making. Mai and Olsen (2016) measured convenience orientation in terms of a desire to spend as little time and effort possible to complete a task. The key components of convenience theory are similar to [5] problem triangle analysis in routine activity theory. Routine activity theory suggests three conditions for crime to occur: a motivated offender, an opportunity in terms of a suitable target, and the absence of a capable or moral guardian. The existence or absence of a likely guardian represents an inhibitor or facilitator for crime.

Another traditional theory is worthwhile to compare to convenience theory. Fraud theory with the fraud triangle suggests three conditions for fraud [1]

a) Incentives and pressures,

b) Opportunities, and

c) Attitudes and rationalization. Incentives and pressures belong in the economical dimension;

Opportunities belong in the organizational dimension; while attitudes and rationalization belong in the behavioral dimension. As such, the fraud triangle covers all dimensions of convenience theory. However, at the core of convenience theory 
is convenience in all three dimensions as well as opportunity found in the organizational setting based on professional role and trust by others. Furthermore, convenience theory emphasizes the relative importance of convenience, where offenders have alternative legitimate actions available to respond to incentives and pressures, but they choose illegitimate actions since these actions are considered more convenient.

\section{Financial Motive}

The motive for white-collar crime is simply financial gain The motive for financial gain, however, can vary. Crime might be a response to both possibilities and threats, and it might be a response to both strengths and weaknesses. An offense can enable exploration and exploitation of a business or a personal possibility that seem otherwise unobtainable. An offense can enable avoidance of business threats or personal threats. An offense can make the business or the personal situation even stronger, and it can reduce and compensate for business or personal weaknesses. Financial gain as motive for white-collar crime can either benefit the individual or the organization. If illegal financial gain benefits the individual, it is labeled occupational crime. The individual benefits personally from illegal economical gain in a setting where his or her occupation enables white-collar crime. The motive for personal financial gain can vary in terms of possibilities and threats, and strengths and weaknesses. Examples of possibilities include increased personal wealth to enjoy as well as enjoyment by providing others - such as relatives and friends - with gifts and benefits. Examples of avoidance of threats include avoidance of personal bankruptcy and avoidance of falling from a high status position based on being rich. Examples of strengths include strengthened role in the local community and increased admiration at work. Examples of compensation for weaknesses include buying friends and compensating for lack of popularity by paying for others.

When financial gain as a motive for white-collar crime benefits the organization, it can again be explained by possibilities, threats, strengths and weaknesses. Possibilities include achieving a new contract and establishing a subsidiary in a corrupt country. Threats include avoidance of bankruptcy for the business, where tax evasion and bank fraud can be relevant forms of white-collar crime. Strengths can be improved in terms of higher share prices and better corporate reputation. Examples of weaknesses that can be compensated by illegal financial gain include avoidance of loss of key personnel, continuation of risky business practices, and growth rather than consolidation in the firm. As discussed so far, there are all kinds of motives and motivations for white-collar crime. A motive is something that causes someone to act in a certain way and do certain things. Similarly, motivation is a theoretical construct used to explain behavior. Motivation represents the reasons for people's actions, desires, and needs. Motivation involves personality and cultural factors that induce individuals to act in ways that neutralize the strong ethical controls of society. Specific cultural factors that lead to crime and criminal behavior include the desire to make a fast buck and the fear of losing what has already been made [6].

Motivation is different from, but at the same time linked to opportunity [7]. Motivation is distinct from opportunity, but the two often intertwine, as when opportunity enhances temptation. As in legitimate enterprise, being able tends to make one more willing, just as being willing increases the prospects of being able. The American dream suggests that everyone in America has the possibility of becoming monetary successful. A high whitecollar crime rate can be attributed to the commitment to the goal of material success as experienced in the American dream. It is caused by an overemphasis on success in exposed assets [8], and it is not matched by a concurrent emphasis on what means are legitimate for reaching desired goals [9]. When fewer people experience that they are unable to live the American dream by mean of law-abiding behavior, then more people will explore alternative avenues to live the American dream.

A white-collar criminal wrote in his autobiography about his American dream [10]. I had lived a version of the American dream: a high school dropout who with ambition, hard work, and a lot of good luck rose to the cusp of one of the highest positions in the land. The American dream emphasizes economic success, while at the same time society is perceived to be restricting individuals' access to legitimate opportunities for upward socioeconomic mobility, which, in turn, can result in high levels of criminogenic anomie in society [9]. The opposite of the American dream theory is the fear of falling theory. While the dream is about climbing in the pyramid, the fear is about falling down from the pyramid. Fear of falling theory suggests that people in leading positions are afraid of consequences from failure and therefore try to survive in their positions by applying various means [11]. They are afraid of falling off the financial cliff and losing their wealth and status. Therefore, they work constantly to remain successful, preferably more successful than others, while not having the time to relax and enjoy wealth because of their fear of failure. It is this struggle for financial success and maintenance of that success which are important to them. The fear of falling leads to solutions to problems such as acute illiquidity in terms of financial crime as the only way out of the crises. Profit-driven crime is thus not only an issue of making even more money. Rather, it is an issue of survival, and it may be about rescuing a sinking ship.

\section{Organizational Opportunity}

The organizational dimension sets white-collar criminals apart from other financial criminals. Abusing social security benefits, committing tax evasion or committing Internet fraud on a personal level is not considered white-collar crime. White-collar crime is defined as financial crime committed in a professional capability in an organizational context. While possibilities in the economical dimension are concerned with convenient abilities 
for achievement of goals (avoid threats and gain benefits such as real estate and foreign establishment), opportunities in the organizational dimension revolves on how crime can be committed conveniently. The economical dimension answers the why question, while the organizational dimension answers the how question of white-collar crime. We distinguish between economic ability to realize wishes, meet needs and fulfill desires, and professional opportunity to implement white-collar crime in connection with regular business activities. Corruption, bank fraud and embezzlement are typical examples of financial crime in professional settings.

An organization is a system of coordinated actions among individuals and groups with boundaries and goals [12]. An organization can be a hierarchy, a matrix, or a network or any other kind of relationships between people in a professional work environment [13]. Ahrne et al. [14] argue that an organization is characterized by membership, hierarchy, monitor and sanctions. Organizations decide about membership, about who will be allowed to join the organization as employees. Membership brings a certain identity with it, an identity that differs from that of non-members. Organizations include a hierarchy, a duty to oblige others to comply with decisions. Hierarchy entails a form of organized power. Organizations can issue commands, and can also decide upon rules that its members are expected to follow in their actions. An organization has the right to monitor compliance with its commands and rules. Organizations have the right to decide about sanctions, both positive and negative. They can decide to change a member's status by using promotions, grading systems, awards, diplomas and medals.

Organizational members have different roles that lead to different extent of power and influence. Some organizational members have to do and also do what they are told. Other members decide what should be done. Power and influence is associated with level in the organizational hierarchy, tasks to be performed, as well as individual freedom. Some members enjoy substantial individual freedom although they can be found at lower levels of the organization.

The organizational anchoring may cause some revealed white-collar criminals to avoid investigation, prosecution and conviction. The business may be too powerful or important to collapse (such as banks), and the criminals may be too powerful to jail. After the downturn in the US economy in 2008, many expected bank executives to be prosecuted, but they were not [15] explain why it did not happen:

From a criminological standpoint, the current financial meltdown points to the need to unpack the concept of status when examining white-collar and corporate offenses. The high standing of those involved in the current scandal has acted as a significant shield to accusations of criminal wrongdoing in at least three ways. First, the legal resources that offenders can bring to bear on any case made against them are significant. This would give pause to any prosecutor, regardless of the evidence that exists. Second, their place in the organization assures that the many below them will be held more directly responsible for the more readily detected offenses. The downward focus on white-collar and corporate crimes is partly a function of the visibility of the offense and the ease with which it can be officially pursued. Third, the political power of large financial institutions allow for effective lobbying that both distances them from the criminal law and prevents the government from restricting them from receiving taxpayer money when they get into trouble. Similar lack of prosecution and punishment can be found in private fraud investigations. For example, [16] identified executive misconduct as the reason for the bankruptcy at Lehman Brothers, but the investigation nevertheless concluded that executives were legally not to blame. Therefore, they were never prosecuted.

The organizational setting focuses on profession and position associated with a business or other kind of entity that makes it possible to carry out criminal acts. A profession is an occupation where a person is eligible by virtue of education and experience. In a narrow sense, a profession is a group of professionals with the exclusive right to perform certain work because they have completed a special education. Examples are medical doctors and attorneys. This definition is too narrow in our context. Profession is here broadly defined as a qualified occupational practice based on knowledge and experience. [17] Argues that organizational culture makes it possible to adopt organizational purposes and objectives, which are basically deviant in comparison with social norms yet in line with the competition. Deviant purposes can be chosen when business corporations are trapped by doubtful, immoral or disloyal means that are used by competitors. They could also be trapped by the business milieu as a social institution. Furthermore, they could be trapped by their own sector-based morality, which is oriented towards profit maximization.

\section{Deviant Behavior}

Most theories of white-collar crime can be found along the behavioral dimension. Numerous suggestions have been presented by researchers to explain famous people who have committed financial crime. In this chapter, some of the most prominent theories are presented: differential association theory, theory of self-control and desire-for-control, slippery slope theory, and neutralization theory. Crime is not committed by systems, routines, or organizations. Crime is committed by individuals. White-collar criminals practice a deviant behavior to carry out their offenses. White-collar crime is committed by members of the privileged socioeconomic class who are using their power and influence. Offenders are typically charismatic, have a need-to-control, have a tendency to bully subordinates, fear losing their status and position, exhibit narcissistic tendencies, lack integrity and social conscience, have no guilt feelings, and do not perceive themselves as criminals. 
Convenience theory argues that white-collar crime is most common among people in their forties, an age when one is most ambitious and opportunities often are the greatest. Ambitions can be significant both on behalf of oneself and on behalf of the organization. At this age, many have taken on positions that enable and make it relatively convenient to carry out financial crime. The maximum extent of criminogenity is normally reached in a time frame where ambitions and opportunities are at a peak. White-collar criminals are often effortlessly both before and after they have committed financial crime. They feel no discomfort at their crime, and they may live well with their crime. This lack of guilt feeling and lack of bad conscience can be explained by a number of behavioral theories, such as neutralization theory and self-control theory. Neutralization techniques help remove potential guilt feeling both before and after an offense, while a lack of self-control causes the threshold for committing an offense to decline.

Many theories applied to white-collar crime and criminals are developed along the behavioral dimension. By behavior is meant human movement patterns, actions and reactions. A person's behavior is the sum of his or her responses to external and internal stimuli. For example, criminals are often more innovative than most people [18]. Researchers have introduced numerous explanations for the behavior of known whitecollar offenders such as Maddoff, Rajaratman and Schilling in the United States. Typical explanations include differential association theory [19], self-control theory [20], slippery slope theory [21], and neutralization theory [22]. Deterrence theory [23], obedience theory [24], and negative life events theory [25] are other relevant theories.

The theories help illustrate how financial crime may be the most convenient action from a behavioral perspective to exploit an opportunity for profit. It is convenient for offenders to abuse their positions, resources and power to inflict losses on others, while at the same time enrich themselves or their organization [26]. Research by Ragatz et al. [27] is an example of work that explores psychological traits among white-collar offenders. Their research results suggest that white-collar offenders have lower scores on lifestyle criminality, but higher score on some measures of psychopathology and psychopathic traits compared to non-white-collar offenders. Similarly, McKay et al. [28] examined the psychopathology of the white-collar criminal acting as a corporate leader. They looked at the impact of a leader's behavior on other employees and the organizational culture developed during his or her reign. They found narcissism, and narcissistic behavior is suggested often to be observed among white-collar offenders [29-32].

Narcissists exhibit an unusually high level of self-love, believing that they are uniquely special and entitled to praise and admiration. [33] Studied a number of well-known whitecollar offenders in the United States and found that many of them identified themselves so strongly with the organization that they regarded themselves as the core of the business. This phenomenon can be called narcissistic identification with the organization. Such a strong identification with the organization can in itself lead to a higher level of white-collar crime. When the organization is perceived as him or her, he or she may argue that he or she is entitled to enrichment at the expense of the organization.

\section{Research Model}

The extent of white-collar crime can be explained by desire in the economical dimension, opportunity in the organizational dimension, and willingness in the behavioral dimension, as illustrated by the research model in (Figure 1). The research model is expected to predict the extent of white-collar crime based on convenience theory.

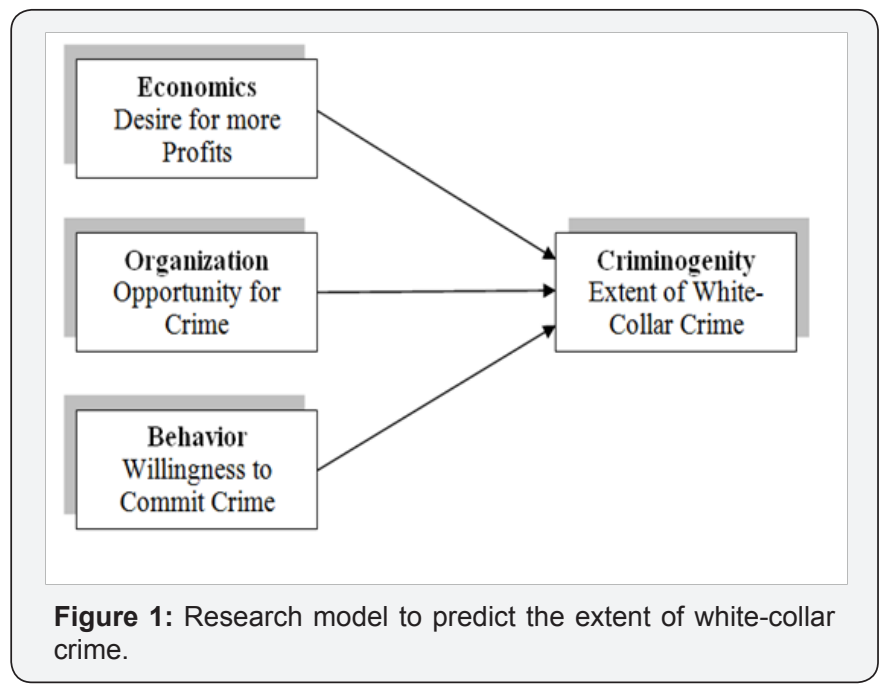

The research model in Figure 1 stimulates the following research hypotheses.

a) Hypothesis I: A stronger desire for more profits will lead to a greater tendency to commit white-collar out of convenience. The economical dimension of convenience theory suggests that the desire for profits is caused by perceived needs. It is convenient to satisfy desires by whitecollar crime.

b) Hypothesis II: A greater organizational opportunity to commit crime will lead to a greater tendency to commit white-collar crime out of convenience. The organizational dimension of convenience theory suggests that the profession and privileged position of the potential offender provides an opportunity to commit crime and makes crime a convenient action.

c) Hypothesis III: A stronger willingness to commit crime will lead to a greater tendency to commit white-collar crime out of convenience. The behavioral dimension of convenience theory suggests that member of the elite are willing to commit white-collar crime. 
We Operationalize Economics as Desire for More Profits in the Following Statements (disagree-agree):

i. Top executives are very concerned about profitability.

ii. Top executives choose convenient solutions to achieve ambitious financial goals.

iii. Top executives choose convenient solutions to satisfy their own financial greed.

iv. Top executives choose convenient solutions when they are exposed to financial stress.

We Operationalize Organization as Opportunity for Crime in the Following Statements (disagree-agree):

I. Top executives have ample opportunities to commit financial crime related to their positions.

II. It is convenient for top executives to commit financial crime in their positions.

III. It is convenient for top executives to express that apparently illegal financial actions are legitimate.

IV. It is convenient for top executives to conceal illegal financial actions among legal actions.

We Operationalize Behavior as Willingness to Commit Crime in the Following Statements (disagree-agree):

a) Top executives are willing to commit financial crime at work.

b) Top executives perceive that financial crime is convenient because they do not look at themselves as criminals.

c) Top executives perceive that financial crime is

Table 1: Variation in criminogenity explained by three predictors. convenient because they lack self-control.

d) Top executives perceive that financial crime is convenient because they think the end justifies the means.

We Operationalize Criminogenity - The Tendency to Commit Crime - As Extent Of White-Collar Crime in the Following Statements (disagree-agree):

i. Top executives often commit financial crime by virtue of their positions.

ii. Financial crime is accepted among top executives.

iii. Top executives often solve challenges by committing financial crime by virtue of their positions.

iv. Top executives have a great tendency to commit financial crime by virtue of their positions.

The research model was applied empirically by these statements in a questionnaire distributed to students in a class on policing financial crime. All thirty-two students filled in the questionnaire in the spring term 2017.

\section{Research Results}

First, each of the four multiple item scales had to be studied in terms of reliability. The Cronbach's alpha turned out to be $.619, .809, .617$ and .768 respectively for economics, organization, behavior, and crime. While two of them are below the acceptable threshold of $\mathrm{p}<.7$, the scales were still applied in this research because of the limited number of respondents. (Table 1) indicates that the three independent variables can predict variation in the dependent variable to a large extent. More than half of the variation in crime tendency is predicted by motive, organization and behavior as indicated by an adjusted $\mathrm{R}$ square of .565 (Table 2).

\begin{tabular}{|c|c|c|c|c|}
\hline \multicolumn{7}{|c|}{ Model Summary } \\
\hline Model & R & R Square & Adjusted R Square & Std. Error of the Estimate \\
\hline 1 &, $779 a$ &, 607 &, 565 &, 84766 \\
\hline \multicolumn{7}{|c|}{ a. Predictors: (Constant), Atferd, Økonomi, Org } \\
\hline
\end{tabular}

Table 2: Variation in criminogenity explained by three predictors.

\begin{tabular}{|c|c|c|c|c|c|c|}
\hline \multicolumn{7}{|c|}{ ANOVA $^{\text {a }}$} \\
\hline \multirow{2}{*}{ Model } & Sum of Squares & df & Mean Square & F & Sig. \\
\hline \multirow{2}{*}{1} & Regression & 31,124 & 3 & 10,375 & 14,439 &, $000^{\mathrm{b}}$ \\
\cline { 2 - 7 } & Residual & 20,119 & 28 &, 719 & \\
\cline { 2 - 7 } & Total & 51,242 & 31 & & \\
\hline \multicolumn{7}{|c|}{ a. Dependent Variable: Krim } \\
\hline
\end{tabular}

The above Table indicates that the regression model is indeed significant with a high F-value of 14.439. 
Table 3: Significance of predictor variables for white-collar crime.

\begin{tabular}{|c|c|c|c|c|c|c|}
\hline \multicolumn{7}{|c|}{ Coefficientsa } \\
\hline \multirow{2}{*}{\multicolumn{2}{|c|}{ Model }} & \multicolumn{2}{|c|}{ Unstandardized Coefficients } & \multirow{3}{*}{$\begin{array}{c}\begin{array}{c}\text { Standardized } \\
\text { Coefficients }\end{array} \\
\text { Beta }\end{array}$} & \multirow{3}{*}{$\begin{array}{c}\mathbf{t} \\
-1,297\end{array}$} & \multirow{3}{*}{$\begin{array}{l}\text { Sig. } \\
, 205\end{array}$} \\
\hline & & B & Std. Error & & & \\
\hline \multirow[t]{4}{*}{1} & (Constant) & $-1,403$ & 1,082 & & & \\
\hline & Økonomi & ,206 & 182 & 139 & 1,129 & ,269 \\
\hline & Org &, 144 &, 142 &, 132 & 1,011 & ,321 \\
\hline & Atferd & ,896 & ,171 & 677 & 5,255 & 000 \\
\hline \multicolumn{7}{|c|}{ a. Dependent Variable: Krim } \\
\hline
\end{tabular}

Table 3 shows that only one of the predictors is by itself significant. While neither financial desire nor organizational opportunity is significant predictor of the tendency to commit white-collar crime, behavior is indeed a very significant predictor. With a steep slope of .677 in the relationship, and a significant relationship at .000 , willingness to get involved in deviant behavior is the main explanation for white-collar crime.

\section{Discussion}

In their classical article on theory building and theory testing, [33] conceptualize theory building as the introduction of constructs and relationships. Work on convenience theory represents theory building as we introduce the construct of convenience and define relationships between desire for profits, opportunity in the organizational context, and willingness for deviant behavior. The introduction of the new construct of convenience creates a departure from existing work by generating a number of new research directions that can shape future thinking [33]. Conceptualize theory testing as the application of theory in an empirical study as a means of grounding a specific set of a priori hypotheses. Testing of convenience theory require delving into underlying processes that explain relationships, touching on neighboring concepts or broader social phenomena, and describing convincing and logically interconnected arguments. Tests described so far do not necessarily satisfy all these requirements.

However, [33] define different levels of theory testing. Their third point on the theory-testing axes seems to fit our testing so far, where predictions are grounded in past conceptual arguments. We explain why a given relationship should exist by asking a population of students to agree or disagree with each statement. Describing the causal logic behind a given prediction and then gaining support for this description supplies a critical ingredient to theory testing. Furthermore, [33] identified five distinct types of research outcomes concerning theories: reporters, testers, qualifiers, builders, and expanders. Our approach seems to fit the description of builders that are relatively high in theory building but relatively low in theory testing. Builders include inductive studies that focus on new constructs, relationships, or processes [33-42].

\section{Conclusion}

Those who believe that top executives often commit financial crime by virtue of their positions, that financial crime is accepted among top executives, that top executives often solve challenges by committing financial crime by virtue of their positions, and that top executives have a great tendency to commit financial crime by virtue of their positions, also believe that top executives have a strong financial desire, organizational opportunity for crime, and willingness to commit crime. In particular, criminogenity is influenced by top executives' willing to commit financial crime at work, top executives perception that financial crime is convenient because they do not look at themselves as criminals, top executives perception that financial crime is convenient because they lack self-control, and top executives perception that financial crime is convenient because they think the end justifies the means.

\section{References}

1. Cressey D (1972) Criminal Organization: It's Elementary Forms. Harper and Row, New York, USA.

2. McMahon R, Pence D, Bressler L, Bressler MS (2016) New tactics in fighting financial crimes: Moving beyond the fraud triangle, Journal of Legal, Ethical and Regulatory Issues 19(1): 16-25.

3. Gottschalk P (2017) Convenience in white-collar crime: Introducing a core concept. Deviant Behavior pp. 605-619.

4. Sundström M, Radon A (2015) Utilizing the concept of convenience as a business opportunity in emerging markets. Organizations and Markets in Emerging Economies 6(2): 7-21.

5. Felson M, Boba RL (2017) Crime and Everyday Life, Chapter 12: "White-Collar Crime", Thousand Oaks, CA: Sage Publications, USA.

6. Aguilera RV, Vadera AK (2008) The Dark Side of Authority: Antecedents, Mechanisms, and Outcomes of Organizational Corruption. Journal of Business Ethics 77(4): 431-449.

7. Steffensmeier D, Allan E (1996) Gender and crime: Toward a gendered theory of female offending. Annual Review of Sociology 22: 459-487.

8. Schoepfer A, Piquero NL (2006) Exploring white-collar crime and the American dream: A partial test of institutional anomie theory. Journal of Criminal Justice 34: 227-235. 
9. Pratt TC, Cullen FT (2005) Assessing macro-level predictors and theories of crime: A meta-analysis. Crime and Justice 32: 373-450.

10. Kerik BB (2005) From jailer to jailed-my journey from correction and police commissioner to inmate \#84888-054, Threshold Editions, New York, USA.

11. Piquero NL (2012) The only thing we have to fear is fear itself: Investigating the relationship between fear of falling and white collar crime. Crime and Delinquency 58 (3): 362-379.

12. Puranam P, Alexy O, og Reitzig M (2014) What's “new" about new forms of organizing? Academy of Management Review 39 (2): 162-180.

13. Dion M (2008) Ethical leadership and crime prevention in the organizational setting. Journal of Financial Crime 15(3): 308-319.

14. Ahrne G, Brunsson N (2011) Organization outside organizations: the significance of partial organization. Organization 18(1): 83-104.

15. Pontell HN, Black WK, ogGeis G (2014) Too big to fail, too powerful to jail? On the absence of criminal prosecutions after the 2008 financial meltdown. Crime Law and Social Change 61(1): 1-13.

16. Valukas AR (2010) In regard Lehman Brothers Holdings Inc. to United States Bankruptcy Court in Southern District of New York. Jenner \& Block pp. 1-791.

17. Dion M (2009) Corporate crime and the dysfunction of value networks. Journal of Financial Crime 16(4): 436-445.

18. Elnan TS (2016) Kriminelleer of temer innovative enn folk flest (-Criminals are often more innovative than most people), daily Norwegian newspaper Aften posten p. 4-5.

19. Sutherland EH (1983) White Collar Crime - The Uncut Version, New Haven, Yale University Press, US.

20. Gottfredson MR, Hirschi T (1990) A general theory of crime, Stanford University Press, Stanford, USA.

21. Welsh DT, Oronez LD, Snyder DG, Christian MS (2014) The slippery slope: How small ethical transgressions pave the way for larger future transgressions, Journal of Applied Psychology 100(1): 114-127.

22. Sykes G, Matza D (1957) Techniques of neutralization: A theory of delinquency. American Sociological Review 22(6): 664-670.

23. Comey JB (2009) Go directly to prison: White collar sentencing after the Sarbanes-Oxley act, Harvard Law Review 122: 1728-1749.

24. Baird JE, Zelin RC (2009) An Examination of the Impact of Obedience Pressure on Perceptions of Fraudulent Acts and the Likelihood of Committing Occupational Fraud. Journal of Forensic Studies in Accounting and Business, Winter 1(1): 1-14.

25. Engdahl O (2015) White-collar crime and first-time adult-onset offending: Explorations in the concept of negative life events as turning points, International Journal of Law, Crime and Justice, 43(1): 1-16.

26. Pickett KHS, Pickett JM (2002) Financial crime investigation and control. John Wiley \& Sons, New York, USA.
27. Ragatz LL, Fremouw W, Baker E (2012) The Psychological Profile of White-Collar Offenders: Demographics, Criminal Thinking, Psychopathic Traits, and Psychopathology. Criminal Justice and Behavior 39 (7): 978-997.

28. McKay R, Stevens C, Fratzi J (2010) A 12-step process of white-collar crime. International Journal of Business Governance and Ethics 5(1): 14-25.

29. Arnulf JK, Gottschalk P (2013) Heroic Leaders as White-Collar Criminals: An Empirical Study, Journal of Investigative Psychology and Offender Profiling, 10: 96-113.

30. Ouimet G (2009) Psychology of white-collar criminal: In search of personality. Psychologie Du Travail Et Des Organisations 15(3): 297320.

31. Ouimet G (2010) Dynamics of narcissistic leadership in organizations. Journal of Managerial Psychology 25(7): 713-726.

32. Galvin BM, Lange D, Ashforth BE (2015) Narcissistic organizational identification. Seeing oneself as central to the organizations identity. Academy of Management Review 40(2): 163-181.

33. Colquitt, Jason A, Cindy P, Zapata-Phelan (2007) "Trends in theory building and theory testing: A five-decade study of the Academy of Management Journal." Academy of Management Journal 50(6): 12811303.

34. Berry LL, Seiders K, Grewal D (2002) Understanding service convenience. Journal of Marketing, 66(3): 1-17.

35. Collier JE, Kimes SE (2012) Only If It is Convenient: Understanding How Convenience Influences Self-Service Technology Evaluation. Journal of Service Research 16(1): 39-51.

36. Farquhar JD, Rowley J (2009) Convenience: a services perspective. Marketing Theory 9(4): 425-438.

37. Mai HTX, Olsen SO (2016) Consumer participation in self-production: The role of control mechanisms, convenience orientation, and moral obligation, Journal of Marketing Theory and Practice, 24(2): 209-223.

38. Piquero NL, Benson ML (2004) White collar crime and criminal careers: Specifying a trajectory of punctuated situational offending. Journal of Contemporary Criminal Justice 20: 148-165.

39. Piquero NL, Schoepfer A, Langton L (2010) Completely out of control or the desire to be in complete control? How low self-control and the desire for control relate to corporate offending. Crime \& Delinquency 56(4): 627-647.

40. Sutherland, Edwin H (1939) "White-collar criminality."American Sociological Review 5: 1-12.

41. Sutherland EH (1949) White-Collar Crime, Holt, Rinehart and Winston Publishing, New York, USA.

42. Valukas AR (2014) Report to board of directors of General Motors Company regarding ignition switch recalls. law firm Jenner \& Block pp. $1-325$. 
(C) Commons Attribution 4.0 License BY DOI: $10.19080 / J F S C I .2017 .04 .555635$

\section{Your next submission with Juniper Publishers} will reach you the below assets

- Quality Editorial service

- Swift Peer Review

- Reprints availability

- E-prints Service

- Manuscript Podcast for convenient understanding

- Global attainment for your research

- Manuscript accessibility in different formats ( Pdf, E-pub, Full Text, Audio)

- Unceasing customer service

Track the below URL for one-step submission https://juniperpublishers.com/online-submission.php 